\title{
HPLC Assessment and Multivariate Predictability of Serum Retinol and $\alpha-$ Tocopherol Concentrations in Adult Female Subjects
}

\author{
Agnieszka Jaworowska and Grzegorz Bazylak*
}

\author{
Department of Pharmaco-Bromatology \& Molecular Nutrition, Faculty of Pharmacy, Collegium Medicum, Nicolaus \\ Copernicus University, Jagiellonska 13, PL-85-067 Bydgoszcz, Poland
}

\begin{abstract}
Antioxidant vitamins have been reported to protect against a variety of human malignances and multiple chronic degenerative diseases therefore it is important to understand factors that influence their blood levels. The present study was conducted to verify association of serum retinol and $\alpha$-tocopherol levels with obesity, and to assess predictors of their serum concentrations in representative sample population of overweight/obese $(n=51)$ and normal weight $(n$ = 26) apparently healthy adult female subjects recruited from typical urban area in Poland. Anthropometric measurements were taken from all participants who also completed a questionnaire on selected lifestyle factors. The serum concentrations of retinol and $\alpha$-tocopherol were measured by fully validated Chromsystems diagnostic kit employing isocratic RPHPLC with switched wavelength UV detection. Intake of energy, fat, vitamin A and E and alcohol consumption were estimated by seven daily dietary records. Multivariate linear regression models were fitted in order to estimate the predictors of serum retinol and $\alpha$-tocopherol concentration. There were no statistically significant differences in the average serum levels of retinol and $\alpha$-tocopherol between overweight/obese and normal weight adult female subjects. Serum $\alpha$ tocopherol concentrations were positively correlated with serum total cholesterol level (TChol) and body mass index (BMI), but inversely with total energy intake and past dieting behaviour. The TChol and total energy intake were identified as predictors of serum retinol levels. Intakes of fat and vitamin E and A, age, serum triglyceride concentration, smoking, alcohol consumption and physical activity were unrelated to serum levels of retinol or $\alpha$-tocopherol. The main finding of this study is that obesity is not associated with decreased serum retinol and $\alpha$-tocopherol levels. In addition, these results indicated that dietary intake of vitamin $\mathrm{A}$ and $\mathrm{E}$ are poor predictors for serum retinol or $\alpha$-tocopherol concentrations. Serum levels of both these vitamins are primarily influenced by TChol, obesity, total energy intake and past dieting behaviour.
\end{abstract}

Keywords: Obesity, human serum, micronutrient status, antioxidant intake, vitamin status.

\section{INTRODUCTION}

The antioxidant vitamins contribute to the body's defense against reactive oxygen species [1]. Retinol and $\alpha$ tocopherol, both for dietary intake and basal serum concentrations, are one of the most widely studied compounds in various populations because of the increasing evidence of their potential role in the prevention of chronic degenerative diseases, such as coronary heart disease, hypertension, stroke, many types of cancer and bone calcification [2-4]. These vitamins exhibit multiple biological actions that may be regulatory in range of the infectious and inflammationrelated diseases $[5,6]$. For example, vitamin A inhibits the transcription of the gene that stimulates the production of reactive oxygen species, affects cell growth regulation and modulates immune response $[1,7,8]$, while vitamin $\mathrm{E}$ is a potent chain breaking antioxidant that protects cell membranes from damage caused by lipid peroxidation $[1,9,10]$. However, contrary to serum $\alpha$-tocopherol, significant inverse relationship between basal serum retinol concentration and both urine as well as leukocyte biomarkers of oxidative

*Address correspondence to this author at the Department of PharmacoBromatology \& Molecular Nutrition, Faculty of Pharmacy, Collegium Medicum, Nicolaus Copernicus University, Jagiellonska 13, PL-85-067, Bydgoszcz, Poland; Tel: +4852 585 3915; Fax: +4852 585 3817;

E-mail: gbazylak@cm.umk.pl
DNA damage, i.e. 8-oxo-7,8-dihydroguanine and 8-oxo-7,8dihydro-2'-deoxyguanosine, in healthy humans has been reported [11] suggesting that this enlarged effect of retinol is exerted via regulation of antioxidant enzymes as like superoxide dismutases SOD1 and SOD2, which can efficiently neutralize reactive oxygen species.

Knowledge of factors that influence retinol and $\alpha$ tocopherol absorption and distribution in human tissues is an important part of understanding the role of these vitamins in nutritional status assessment and their function in obesity associated diseases. It was observed that there are no straightforward associations between dietary intake of retinol and $\alpha$-tocopherol and their serum concentration due to individual differences in absorption, metabolism and tissue distribution of retinol and $\alpha$-tocopherol [12,13]. Several published reports have identified that intake of other nutrients, smoking, alcohol comsumption, plasma lipid profile, age and obesity affect serum concentrations of these vitamins [14$18]$. Obesity is associated in some instances with lower levels of serum fat-soluble antioxidants [18, 19]. Simultaneously, in obesity the risk of developing resistance to insulin, lipid alterations and of being subjected to oxidative stress is higher [20]. This is associated with the presence of low serum concentrations of antioxidant vitamins which might be the factor that increases the risk of incidence of a nontransmissible chronic diseases, particularly the cardiovascu- 
lar ones. In this context, the involvement of overexpression of a novel adipokine, i.e. retinol binding protein 4 (RBP4), in visceral and subcutaneous fat into development of insulin resistance in overweight/obese female subjects have been considered recently [21].

Poland belongs to group of countries where obesity and comorbidities associated with obesity, especially cardiovascular disease, are the major health problem [22]. Taking into account the potential role of retinol and $\alpha$-tocopherol in preventing ageing degenerative disease, there is an urgent need to monitoring antioxidant vitamins status in various socioeconomic groups [23, 24]. Because of a lack of current information about antioxidant vitamins level and predictors of their serum concentration in apparently healthy, middle-aged females in Poland, the aim of the present study was 1) to estimate serum concentrations of retinol and $\alpha$-tocopherol, 2) verify their association with common obesity indices and 3 ) determine which dietary intake measures, lipid profile indices and lifestyle factors were related to these vitamins status.

\section{EXPERIMENTAL}

\subsection{Study Population}

The studied population comprised study group of 51 overweight/obese (ov/ob) women (BMI $\geq 25 \mathrm{~kg} / \mathrm{m}^{2}$ ) and control group of 26 normal weight (nw) women (BMI $<25$ $\mathrm{kg} / \mathrm{m}^{2}$ ) matched for age. Subjects were recruited from local community (Bydgoszcz, Poland) during the period from March 2006 to March 2007. Subjects were considered healthy if they indicate no medical history, abnormalities in the physical examination, declared no history of alcohol or narcotic abuse, and were not currently pharmacologically treated for any reason. All participants received detailed information about the aim of this study and provided written consent for their participation in the study before data collection. Research was conducted according to protocols complied with requirements of the Bioethics Committee in Poland and was approved by the local institutional review board.

\subsection{Dietary Assessment}

Usual dietary intake was assessed by seven daily dietary records (five weekdays and two weekend days) according to guidelines of the National Food and Nutrition Institute (Warsaw, Poland) [25]. Participants were individually instructed by a nutritionist on how to complete the records and were asked to note all foods and beverages consumed during seven consecutive days. Participants had to record: time, place, detailed description of foods and beverages, quantity in standard household measures and brand of manufactured foods. Food quantities were assessed by use of kitchen weight scale and comparison with photographs of food products and dishes [26]. All completed records were rechecked by trained person together with the participants, especially about portion size and home meal preparation methods. Average energy, nutrient intake and alcohol consumption of participants was calculated using the "Dieta 2" software with database containing Polish food composition tables [27]. Vitamin E and A values were estimated in $\alpha$-tocopherol and retinol equivalents, respectively.

\subsection{Anthropometric Measurements}

Anthropometric measurements included weight (kg), height $(\mathrm{cm})$, waist circumferance $(\mathrm{cm})$, hip circumferance (cm) and four skinfolds thickness (triceps, biceps, subscapular and suprailiac, $\mathrm{mm}$ ) were taken by a single trained person. Weight was determined to the nearest $0.1 \mathrm{~kg}$ using a digital electronic scale (Radwag, Radom, Poland) with the subjects wearing light indoor clothing and no shoes. Height was measured to the nearest $0.5 \mathrm{~cm}$ using a height scale (Radwag). Body mass index (BMI $\mathrm{kg} / \mathrm{m}^{2}$ ) and percentage of body fast mass $(\% \mathrm{FM})$ was then calculated [22]. Waist and hip circumferance of each participant were measured to the nearest $0.1 \mathrm{~cm}$ and were used to calculate waist to hip ratio (WHR). Three consecutive measurements of skinfolds thickness were performed to the nearest $0.1 \mathrm{~mm}$ using electronic skinfold caliper Skyndex I (Caldwell-Justiss \& Co., Fayetville, AR, USA) and mean values were reported. The Durnin and Womersley formula was applied to calculate total body fat [28].

\subsection{Lifestyle Questionnaire Data}

A multiple-choice questionnaire was used to collect information on smoking, physical activity and dieting. Smoking status was determined from the answers to following questions: "Have you smoked during your entire life?" and "Do you smoke cigarettes now?" On the basis of the responses to these two questions, subjects were divided into three smoking categories: nonsmokers, past smokers and current smokers. Participants were also asked to report whether they have ever been on diet (possible response yes/no). Physical activity level was rated as active if participants reported everyday intensive physical activity (min. 20 minutes per day), moderate if they reported 3 times per week intensive physical activity (minimum 20 minutes per day) and low (no physical activity). The questionnaire also included questions about use of vitamin supplements or lipid lowering drugs.

\subsection{Biochemical Analyses}

Fasting venous blood samples were taken from all volunteers and serum was separated by centrifugation $(3000 \mathrm{~g}$ for $10 \mathrm{~min})$. Serum samples were stored at $-40^{\circ} \mathrm{C}$ until biochemical analysis were performed. Serum levels of triglyceride (TG), total cholesterol (TChol) and high density lipoprotein (HDL) cholesterol were performed in fresh serum at an accredited analytical laboratory by standard enzymatic methods using reagents from Limarco (Olsztyn, Poland) and an automated analyzer BTS 310 (Biosystems, Barcelona, Spain). Low density lipoprotein (LDL) cholesterol concentration was computed as the difference between TChol and HDL cholesterol and TG divided by five [29]. Detection limit was $18 \mu \mathrm{mol} / \mathrm{L}$ and $8 \mu \mathrm{mol} / \mathrm{L}$, with linearity up to 6.78 $\mathrm{mmol} / \mathrm{L}$ and $26 \mathrm{mmol} / \mathrm{L}$, in case of TG and TChol determination, respectively. The intra-assay coefficient of variation (CV) characterizing repeatability was $<1.7 \%$ and $<1.1 \%$, while the inter-assay $\mathrm{CV}$ related with reproducibility was $<$ $2.6 \%$ and $<1.9 \%$ for, respectively, TG and TChol analyses.

\subsection{Vitamin Analyses by HPLC}

Serum $\alpha$-tocopherol and retinol concentrations were determined simultaneously by reversed-phase highperformance liquid chromatography (RP-HPLC) single run 
assay after sample preparation with commercially available ready-to-use reagents kit (Chromsystems Instruments and Chemicals GmbH, Munchen, Germany, cat. No.34000). Firstly, $200 \mu \mathrm{L}$ serum and $20 \mu \mathrm{L}$ internal standard (cat. No. 34008 ) and $25 \mu \mathrm{L}$ precipitation reagent I (cat. No. 34006) were added into a light protected reaction vial and vortexed by $30 \mathrm{~s}$. Then to each vial $400 \mu \mathrm{L}$ precipitation reagent II (cat. No. 34003) was added, vortexed again 30 s, and centrifuged at $9000 \mathrm{~g}$ for $10 \mathrm{~min}$. Next $20 \mu \mathrm{L}$ of the clean supernatant was injected into the HPLC system employing dedicated standard-bore RP-HPLC column $(150 \times 4.6 \mathrm{~mm}$ i.d. $)$ (Chromsystems Instruments and Chemicals $\mathrm{GmbH}$, cat. No. 34100) prepacked with $3 \mu \mathrm{m}$ highly end-capped octadecylsilica and operated using the isocratic elution mode at room temperature $\left(22{ }^{\circ} \mathrm{C}\right)$ with a supplier prepared (Chromsystems Instruments and Chemicals $\mathrm{GmbH}$, cat. No.34100) aqueousmethanol mobile phase. The high-grade quality water with resistivity $18.2 \mathrm{M} \Omega$ was obtained by purification of demineralised water in a Synergy filtration system (Millipore SAS, Molsheim, France).

The HPLC analyses were performed on a LaChrom-Elite L-2130 (Merck-Hitachi-VWR International, Darmstad, Germany) solvent delivery module equipped with a Rheodyne Model $7725 \mathrm{i}$ injection valve with $20 \mu \mathrm{L}$ sample loop (Phenomenex, Torrance, CA, USA), a mobile phase degasser Degassex DG-440 (Phenomenex) and L-2400 programmable, multiwavelength UV-VIS detector (VWR-Hitachi, Darmstad, Germany). All chromatograms were registered using a Chroma integrator (Pol-Lab, Warsaw, Poland) connected with Chromax 2005 software (Pol-Lab) implemented on a desk-top microcomputer working under Windows 95 (Microsoft, Redmond, WA, USA) operating system. The flow rate of mobile phase was $1.5 \mathrm{~mL} / \mathrm{min}$. Detection was carried out at $325 \mathrm{~nm}$ from 0 to $3.5 \mathrm{~min}$ for retinol and at 295 $\mathrm{nm}$ from 3.5 to $12 \mathrm{~min}$ for $\alpha$-tocopherol determination. The baseline was automatically adjusted to zero with each wavelength change.

The pre-tested, lyophilised human serum calibration standard (cat. No. 34004) and set of spiked human serum controls (cat. No. 340032,36,37) supplied directly from Chromsystems (Germany) with concentration of each vitamin at four different levels were used, after reconstitution with doubly distilled water and subjected with the sample preparation process, to calibrate the HPLC system in time of serum samples measurements, as well as during repeatability (precision) and reproducibility (accuracy) study of described here analytical procedure. In addition, for testing of chromatographic performance of the HPLC system and checking the identity and consistency of separated peaks the retinol, $\alpha$ tocopherol and DL- $\alpha$-tocopherol acetate supplied from Sigma ( St. Louis, MO, USA) were applied as the reference standards after their dissolution $(3.00 \mathrm{mg}$ per $10 \mathrm{~mL})$ in gradient-HPLC grade methanol (Merck, Darmstadt, Germany). All these stock solutions were stored in dark brown glass vials at $-20{ }^{\circ} \mathrm{C}$. These reference standard substances were also used to spiking the pooled blank human serum standard (Sigma) in time of measurements of calibration lines and vitamins recovery study.

The internal standard method was used for quantitation of each vitamin $\left(C_{\mathrm{vit} / \mathrm{sample}}, \mu \mathrm{mol} / \mathrm{L}\right)$ in the sample serum according to the formula:
$C_{\text {vit } / \text { sample }}=\left\{\left(I S_{\text {calib }} \times A_{\text {sample }}\right) /\left(I S_{\text {sample }} \times A_{\text {calib }}\right)\right\} \times C_{\text {vit } / \text { calib }}$

where $I S_{\text {calib }}$ is the peak area of internal standard in chromatogram of calibration standard, $A_{\text {sample }}$ is the peak area of specified vitamin in chromatogram of sample serum, $I S_{\text {sample }}$ is the peak area of internal standard in chromatogram of sample serum, $A_{\text {calib }}$ is the peak area of specified vitamin in chromatogram of calibration standard, and $C_{\text {vit/calib }}$ is the concentration of specified vitamin in calibration standard $(\mu \mathrm{mol} / \mathrm{L})$.

To avoid possible sample memory effect due to direct injection of the deproteinized serum sample [30] the syringes and injection valve were rinsed five times with methanol between each serum sample injection. Next, ten $20 \mu \mathrm{L}$ portions of acetonitrile was injected at the end of each day of analysis as the cleaning solvent to ensure that the column would not deteriorate. In addition after a series of each 100 subsequent measurements the HPLC column was replaced by the union and the whole HPLC system was rinsed with 50 $\mathrm{mL}$ of aqueous-methanol $(80: 20, \%, \mathrm{v} / \mathrm{v})$ mixture.

\subsection{Statistical Methods}

All statistical analyses were performed with Statistica PL v. 6.1 software (Stat-Soft, Inc., Tulsa, OK, USA). The results related with study of female subjects were expressed as mean \pm standard deviation (SD) for continuous variables, and as frequency distributions for categorical variables. Dietary intake measures, alcohol consumption, TG, TChol, HDL and LDL cholesterol as well as serum $\alpha$-tocopherol and retinol concentrations were $\log$ transformed before analyses to improve normality. Differences between ov/ob and nw subjects regarding baseline characteristic were tested by the Mann Whitney U-test and chi-square test, as applicable. Pearson's correlation coefficients (r) were computed to assess associations of dietary intake, obesity indicators, lipid profile and lifestyle factors (smoking, dieting, alcohol consumption and physical activity) with serum retinol and $\alpha$-tocopherol concentrations. Multiple linear regression models were applied to assess the factors related to the serum levels of retinol and $\alpha$-tocopherol. The independent variables were age, smoking, alcohol consumption, BMI, TChol and TG, dietary intakes of total energy, fat, vitamin $\mathrm{E}$ and $\mathrm{A}$. The established significance level was $\mathrm{p}<0.05$.

\section{RESULTS}

\subsection{Quality Assurance of HPLC Procedure}

The data characterizing analytical performance and validation criteria of used RP-HPLC procedure for determination of retinol and $\alpha$-tocopherol in serum samples are summarized in Table 1 . The highly selective $(\alpha>2.0)$ and baseline separation $\left(R_{s}>10\right)$ of both vitamins and internal standard with highly symmetrical peaks $\left(\mathrm{A}_{\mathrm{s}}<1.1\right)$ was obtained in total analysis time of below 12 minutes by reproducible $(\mathrm{RSD}<1.50 \%)$ single run isocratic RP-HPLC measurements. The exemplary chromatogram of particular vitamins in serum of one studied female subject is presented in Fig. (1). The observed efficiency of used here RP-HPLC procedure is comparable with previously reported isocratic separation of retinol and $\alpha$-tocopherol using methanol as the single component mobile phase and Hypersil ODS $(600 \times 4.6 \mathrm{~mm}$ i.d.) or $\mu$ Bondapak $\mathrm{C} 18(300 \times 3.9 \mathrm{~mm}$ i.d. $)$ columns as described by Milne et al. [31] and Nirungsan et al. [32], 
respectively. Compare to the RP-HPLC analysis of these vitamins in serum with poli-functional Spheri-5-ODS column and acetonitrile/methylene chloride/methanol gradient elution mode reported by Olmedilla et al. [33-35] the quite analogous retention time of retinol and $\alpha$-tocopherol was obtained in described here isocratic RP-HPLC procedure.

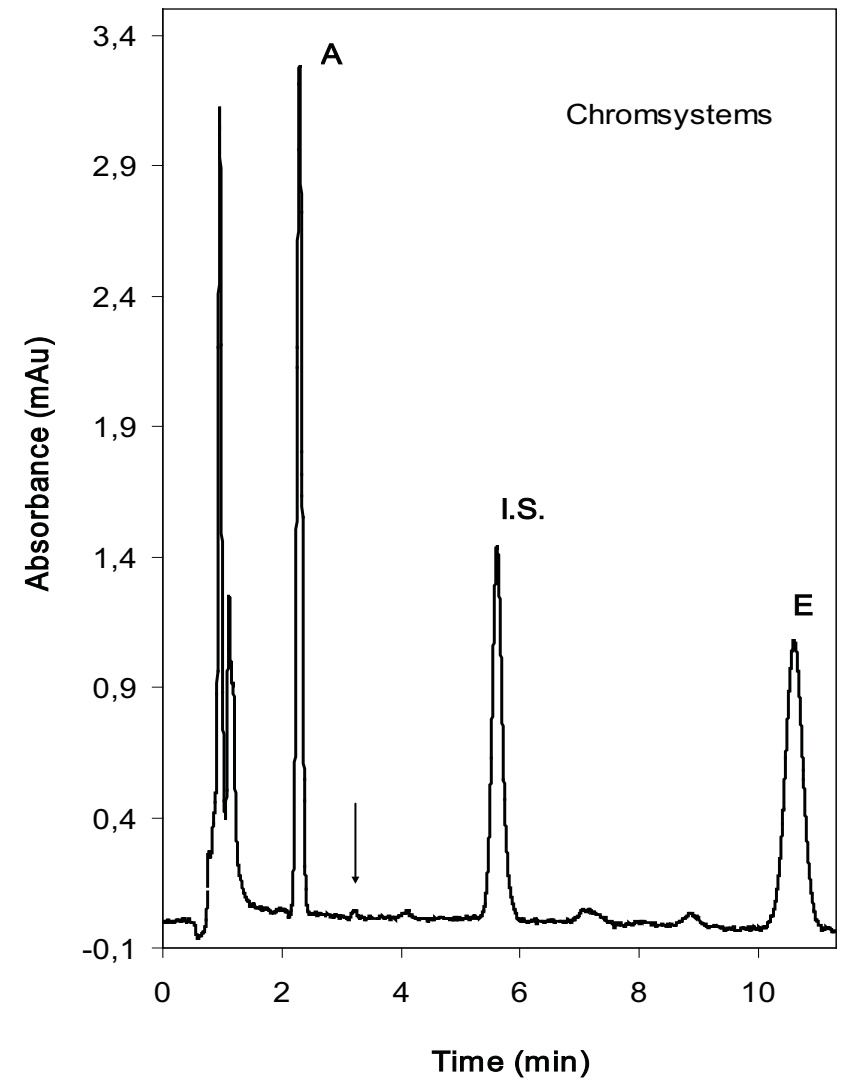

Fig. (1). Separation of retinol (A), internal standard (I.S.) and $\alpha$ tocopherol (E) isolated from healthy adult female serum with Chromsystems HPLC column. Switching of detection wavelength from 325 to $295 \mathrm{~nm}$ is indicated by arrow. See Experimental for measurements details.

The specifity of the applied HPLC method was confirmed by comparison of retention times with reference standard vitamins. The selectivity of method was confirmed by checking of homogeneity spectra of both vitamins, as expressed by Pearson's correlation coefficient (r), when using on-line determination of their UV spectra which provide the confirmation of identity of the analyte with reference spectrum. The (r) value higher than 0.99 would means acceptable peak homogeneity and purity. At the concentration near to their LOQ the calculated matching factors were 0.9986 and 0.9978 for retinol and $\alpha$-tocopherol, respectively, thus the overlay of both vitamins spectra captured automatically at the apex, up slope, and down slope from a reference solution and sample serum was perfect. Absorbance ratios recorded across the respective chromatographic peaks with two pairs of wavelengths (data not shown) did not give any significant deviation in ratio under the conditions used, thus ability for permitting a precise and accurate quatitative determination of each vitamin in sample serum by proposed RP-HPLC procedure was confirmed.

Validation parameters of the used HPLC method were evaluated according to the current ICH guideline [36]. In this calculations the peak area of retinol and $\alpha$-tocopherol were corrected for their retention time. Parameters of calibration lines for each vitamin, as relationship between UV detector response (peak areas) and known vitamin concentration in spiked serum (calibration standard) ranging from 1.64 to $10.00 \mu \mathrm{mol} / \mathrm{L}$ for retinol and from 17.70 to $120.00 \mu \mathrm{mol} / \mathrm{L}$ in case of $\alpha$-tocopherol, were calculated by linear regression procedure available in Statistica software. Good linearity of these calibration lines over the physiological range, up to $8.00 \mu \mathrm{mol} / \mathrm{L}$ for retinol and up to $105.00 \mu \mathrm{mol} / \mathrm{L}$ for $\alpha-$ tocopherol, is indicated by the high values of correlation coefficient (r) and determination coefficient $\left(\mathrm{r}^{2}\right)$ as presented in Table 1. The values of these statistical indices confirm the previous suggestions of Nirungsan and Thongnopnua [32] that the proper choice of the blank pooled human serum and use of multiple-point standard addition method for construction of the calibration lines caused that endogenous retinol and $\alpha$-tocopherol in the blank would not affect the analyzed concentrations of these vitamins and same-day as well between-day variation of analyses was significantly reduced.

Precision was evaluated as the repeatability which is expressed via relative standard deviation of peak areas (RSD $<1.5 \%$ ) measured within the concentration range of calibration line as well as RSD of retention times for each vitamin $(<2.0 \%)$. Precision of RP-HPLC measurements is acceptable what is clearly visible from the values of standard deviations of intercept and slope of calibration lines, i.e. $s_{a}$ and $\mathrm{s}_{\mathrm{b}}$, respectively, and residual sum of squares (RSS $<120$ ). Slightly worst values are observed for second eluted $\alpha$ tocopherol, which can be explained by effect of increased dissolution of this analyte on the HPLC column during retention $[23,37]$.

Limit of detection (LOD) and limit of quantitation (LOQ), being the lowest concentration that can be quantified with acceptable accuracy (RSD $<20 \%$ ) [56], were calculated as the ratio of the standard deviation of the y-intercept of calibration line $\left(s_{a}\right)$ and the slope of this line (b) multiplied by factor 3.3 or 10.0 , respectively. The precision of LOD is fairly good (ca. $2.5 \%$ ) as indicate the values of $\left(\mathrm{s}_{\mathrm{a}}\right)$ and $\left(\mathrm{s}_{\mathrm{b}}\right)$ of intercept and slope of calibration lines. The limit of quantification (LOQ) of this HPLC procedure for retinol and $\alpha$ tocopherol was $0.070 \mu \mathrm{mol} / \mathrm{L}$ and $0.160 \mu \mathrm{mol} / \mathrm{L}$, respectively. The obtained LOQ values clearly indicates that used HPLC procedure enable robust and reliable determination of both vitamins in serum far below the cut-off points considered as marginal, i.e. $<1.05$ and $<16.25 \mu \mathrm{mol} / \mathrm{L}$ for retinol and $\alpha$-tocopherol, respectively [33,34,38]. Similarly, sensitivity of this procedure is acceptable in determination of these vitamins below the cut-off points of inadequacy, i.e. 0.7 and $12 \mu \mathrm{mol} / \mathrm{L}$ for retinol and $\alpha$-tocopherol, respectively $[8,9,11,33,34,38,39]$.

Repeatability and reproducibility of the HPLC method used for determination of vitamins in females serum was estimated by calculation of intra- and inter-assay coefficient of variation (CV), respectively, using serum calibration standard spiked at four (or three) different levels of these vitamins concentration. It is seen that repeatability of retinol determination is increased $(\mathrm{CV}<1 \%)$ compare to $\alpha$ tocopherol $(\mathrm{CV}<2 \%)$, especially at higher concentration levels, but assay reproducibility of both vitamins is quite 
Table 1. Characteristics of HPLC Method and Parameters of Calibration Lines of Retinol and $\alpha$-Tocopherol Measured with Spiked Serum Calibration Standards $(\mathbf{n}=10)$. For Separating Conditions See Experimental Section

\begin{tabular}{|c|c|c|c|}
\hline Parameter & Retinol & I.S. & $\alpha$-Tocopherol \\
\hline Retention time, $\mathrm{t}_{\mathrm{R}} \pm \mathrm{SD}(\mathrm{min})$ & $2.295 \pm 0.034$ & $5.608 \pm 0.095$ & $10.588 \pm 0.221$ \\
\hline Retention factor, $\log k$ & 0.146 & 0.687 & 1.003 \\
\hline Selectivity, $\alpha$ & - & 3.476 & 2.071 \\
\hline Resolution, $\mathrm{R}_{\mathrm{s}}$ & - & 13.963 & 11.522 \\
\hline Column efficiency, $\mathrm{N}$ & 8650 & 18100 & 36300 \\
\hline Peak asymmetry, $A_{s}$ & 0.968 & 1.015 & 1.158 \\
\hline Repeatability of peak area, RSD (\%) & 1.23 & 0.97 & 1.31 \\
\hline Reproducibility of peak area, RSD (\%) & 1.41 & 1.10 & 1.51 \\
\hline Calibration line: Intercept $\pm \mathrm{SD}, \mathrm{a} \pm \mathrm{s}_{\mathrm{a}}$ & $-0.2796 \pm 0.0120$ & $-0.5697 \pm 0.0046$ & $-12.3430 \pm 0.0232$ \\
\hline Calibration line: Slope $\pm \mathrm{SD}, \mathrm{b} \pm \mathrm{s}_{\mathrm{b}}$ & $1.7283 \pm 0.005$ & $1.2156 \pm 0.002$ & $1.4719 \pm 0.0150$ \\
\hline Residual sum of squares, RSS & 105.1 & 95.7 & 115.4 \\
\hline Correlation coefficient, $\mathrm{r}$ & 0.9999 & 0.9999 & 0.9998 \\
\hline Determination coefficient, $\mathrm{r}^{2}$ & 0.9998 & 0.9998 & 0.9997 \\
\hline Mean recovery $\pm \mathrm{SD},(\%)$ & $103.4 \pm 4.1[1.64 *]$ & $102 \pm 3.4\left[1.50^{*}\right]$ & $97.7 \pm 3.9\left[17.70^{*}\right]$ \\
\hline $\mathrm{LOD}(\mu \mathrm{mol} / \mathrm{L})$ & 0.023 & 0.010 & 0.052 \\
\hline $\mathrm{LOQ}(\mu \mathrm{mol} / \mathrm{L})$ & 0.070 & 0.038 & 0.160 \\
\hline Linearity $(\mu \mathrm{mol} / \mathrm{L})$ & up to 8.00 & up to 120.00 & up to 105.00 \\
\hline Intra-assay precision, $\mathrm{CV}(\%)$ & $\begin{array}{c}2.45[1.64 *] \\
0.78[2.30] \\
0.83[3.00] \\
0.92[3.91]\end{array}$ & $\begin{array}{c}2.15\left[1.50^{*}\right] \\
0.73[2.10] \\
0.82[3.10] \\
0.78[4.00]\end{array}$ & $\begin{array}{c}2.52[17.70 *] \\
1.65[24.82] \\
1.97[22.97] \\
2.15[32.48]\end{array}$ \\
\hline Inter-assay precision, CV (\%) & $\begin{array}{c}2.67[1.64 *] \\
2.75[3.00] \\
3.10[3.91]\end{array}$ & $\begin{array}{c}2.17[1.50 *] \\
2.35[2.10] \\
2.52[3.10]\end{array}$ & $\begin{array}{c}3.15[17.70 *] \\
3.80[22.97] \\
3.65[32.48]\end{array}$ \\
\hline
\end{tabular}

Notes: $t_{R}$ - non-corrected retention time; $k=\left(t_{R}-t_{O}\right) / t_{O}$ retention factor; $\alpha=k_{2} / k_{l}$ separation factor calculated for adjacent substances in this table; $t_{O}-$ determined as time of methano (solvent) peak; $R_{\mathrm{s}}=2 \times\left[\left(t_{R 2}-t_{R I}\right) /\left(w_{l}+w_{2}\right)\right]$ resolution ; LOD $=3.3 \times\left(\mathrm{s}_{\mathrm{a}} / \mathrm{b}\right)$ limit of detection; $\mathrm{LOQ}=10 \times\left(\mathrm{s}_{\mathrm{a}} / \mathrm{b}\right)$ limit of quantitation; $*$ concentration level $(\mu \mathrm{mol} / \mathrm{L})$ in serum calibration standard.

comparable and uniform in the whole concentration range studied (CV ca. 4\%).

Recovery was evaluated by spiking of blank standard human serum with retinol and $\alpha$-tocopherol at low concentration level of 1.64 and $17.70 \mu \mathrm{mol} / \mathrm{L}$, respectively, and comparing peak areas of each vitamin in 10 subsequent measurements. The resulting values were slightly over $100 \%$ for retinol and little than this cut-off in case of $\alpha$-tocopherol. Accuracy evaluated through the recovery test was acceptable for both vitamins as the relative error of their determination not exceed $5.0 \%$. The robustness of the method was confirmed by not significant fluctuations of vitamins retention times, peak asymmetry, high precision and accuracy of peak areas, superior peak homogeneity, stable and broad range calibration lines, and high recovery and uniform repeatability and reproducibility at each concentration level, thus indicating that this procedure enable to avoid any potential artifactual peak formation caused by sample memory effects during chromatographic process.

The lack of sample memory effects and detectable interferences on the clean chromatographic peaks of retinol, internal standard and $\alpha$-tocopherol and high recovery of all these substances from the serum samples clearly demonstrates that highly appropriate deproteinization method was used in serum sample preparation step (see Experimental). This was enabled by the superior combination of some specific factors in this procedure, as listed by Nirungsan and Thongnopnua [32], and defined as critical in such operation: 1) optimal composition and minimized volume of deproteinizing agents, 2) full miscibility of deproteinizing agents with water, 3) minimized dilution of serum sample during deproteinization, 4) high stability of internal standard in deproteinizing medium, 5) elimination of solvent extraction, evaporation to dryness, and reconstitution steps, 6) evoiding of possible oxidation of both vitamins, 7) full miscibility of the final clear supernatant with mobile phase, 8) less timeconsuming, high throughput and simplicity.

\subsection{Vitamins Status of Female Subjects}

The characteristic of participants is shown in Table 2. The mean body mass index, percentage of body fat as well as total cholesterol and triglyceride concentration were higher in ov/ob group in comparison with nw individuals. No statistically significant differences were observed in the averages serum 
levels of retinol and $\alpha$-tocopherol between ov/ob and nw groups. Because of the relation between serum $\alpha$-tocopherol and lipids, the results for $\alpha$-tocopherol were also lipid-adjusted as the $\alpha$-tocopherol/TChol and $\alpha$-tocopherol/TChol + TG indices (see Table 2). Lipid adjusted $\alpha$-tocopherol concentrations were similar in both groups. None of the subjects took vitamins supplement or lipid lowering drugs. More nw subjects than ov/ob had never smoked and more ov/ob subjects were past or current smokers. Past dieting behaviour were more frequent among ov/ob individuals. There was significant difference between groups in reported level of physical activity, but ov/ob subjects preferred sedentary life style. Dietary intake of vitamin A and E was similar among groups, but intake of fat and total energy was significantly greater in obese group.

There were numerous factors associated with serum retinol and $\alpha$-tocopherol concentrations (Table 3). The vitamins had a synergistic and statistically significant correlation with each other $(\mathrm{r}=0.386 ; \mathrm{p}=0.0010)$. As expected, serum $\alpha$ tocopherol concentrations were strongly correlated with serum total cholesterol concentrations TChol $(\mathrm{r}=0.682 ; \mathrm{p}<$ 0.0001 ) and moderately with other serum lipids (TG, LDL and HDL cholesterol). Serum level of retinol was also found to be positively correlated with serum triglyceride, TChol and LDL cholesterol concentrations. The BMI, \%FM and WHR were positively and statistically significant associated with serum $\alpha$-tocopherol concentration with $\mathrm{r}=0.274$, 0.231 , and 0.287 , respectively. Whereas, none obesity indicators were related to sera levels of retinol. Past dieting behaviour were inversely related to serum level of $\alpha$-tocopherol $(\mathrm{r}=-0.352 ; \mathrm{p}=0.002)$, but no correlation was observed with serum concentration of retinol. Age was directly associated with serum levels of $\alpha$-tocopherol and retinol. While smoking, alcohol consumption, physical activity and dietary variables were not related neither to serum $\alpha$-tocopherol nor retinol concentration.

To investigate interrelationships of factors influencing serum levels of $\alpha$-tocopherol and retinol, multiple linear regression analyses were carried out (Table 4). A model that included TChol, age, intakes of energy, fat and vitamin E, BMI, alcohol consumption, smoking, past dieting and physical activity explained $53.5 \%$ of the variance in serum concentration of $\alpha$-tocopherol. The same model but changing the corresponding vitamin intake explained $16.3 \%$ of the variance in serum level of retinol. When other variables were controlled, in this case only TChol and energy intake were significantly associated with sera levels of retinol. Instead, the multivariate analyses of $\alpha$-tocopherol indicated that there were numerous

Table 2. Characteristics of the Study Population

\begin{tabular}{|c|c|c|c|c|}
\hline \multirow{2}{*}{ Variables } & \multicolumn{2}{|c|}{ Ov/ob group $(n=51)$} & \multicolumn{2}{|c|}{ Nw group $(n=26)$} \\
\hline & Mean \pm SD & Range & Mean \pm SD & Range \\
\hline Age (years) & $46.6 \pm 11.8$ & $22-69$ & $40.0 \pm 15.9$ & $21-62$ \\
\hline BMI $\left(\mathrm{kg} / \mathrm{m}^{2}\right)$ & $32.6 \pm 4.5$ & $25.5-41.8$ & $21.7 \pm 1.8^{* 1}$ & $18.7-24.8$ \\
\hline$\% \mathrm{FM}(\%)$ & $41.7 \pm 3.3$ & $35.5-49.6$ & $29.9 \pm 5.6^{* 1}$ & $21.5-39.9$ \\
\hline WHR & $0.84 \pm 0.05$ & $0.69-0.99$ & $0.76 \pm 0.06$ & $0.68-0.88$ \\
\hline Serum retinol $(\mu \mathrm{mol} / \mathrm{L})$ & $2.39 \pm 0.56$ & $0.80-4.07$ & $2.33 \pm 0.75$ & $0.37-3.54$ \\
\hline Serum $\alpha$-tocopherol $(\mu \mathrm{mol} / \mathrm{L})$ & $33.1 \pm 10.6$ & $13.2-55.0$ & $29.9 \pm 6.9$ & $8.1-56.2$ \\
\hline TChol $(\mathrm{mmol} / \mathrm{L})$ & $5.30 \pm 0.87$ & $0.97-7.12$ & $4.86 \pm 1.02^{* 1}$ & $0.97-6.83$ \\
\hline $\mathrm{TG}(\mathrm{mmol} / \mathrm{L})$ & $1.25 \pm 0.41$ & $0.67-2.49$ & $0.97 \pm 0.31^{*_{1}}$ & $0.57-2.00$ \\
\hline HDL cholesterol $(\mathrm{mmol} / \mathrm{L})$ & $1.73 \pm 0.26$ & $1.25-2.17$ & $1.71 \pm 0.35$ & $1.15-2.15$ \\
\hline LDL cholesterol (mmol/L) & $2.80 \pm 0.93$ & $1.71-4.84$ & $2.76 \pm 0.80$ & $1.25-3.88$ \\
\hline$\alpha$-Tocopherol/TChol $(\mu \mathrm{mol} / \mathrm{mmol})$ & $6.35 \pm 1.50$ & $3.30-10.05$ & $6.13 \pm 1.13$ & $4.34-8.85$ \\
\hline$\alpha$-Tocopherol/TChol + TG $(\mu \mathrm{mol} / \mathrm{mmol})$ & $5.15 \pm 1.24$ & $2.75-8.49$ & $5.09 \pm 0.88$ & $4.00-12.96$ \\
\hline Energy intake $(\mathrm{kcal} / \mathrm{d})$ & $1830 \pm 417$ & $887-2787$ & $1669 \pm 270^{* 1}$ & $1301-2176$ \\
\hline Fat intake $(g / d)$ & $76.8 \pm 22.9$ & $28.1-128.6$ & $63.3 \pm 15.8^{* 1}$ & $40.5-93.8$ \\
\hline Vitamin A intake $(\mu \mathrm{g} / \mathrm{d})$ & $957 \pm 380$ & $399-2096$ & $83.5 \pm 395$ & $419-1965$ \\
\hline Vitamin E intake (mg/d) & $9.2 \pm 3.4$ & $3.8-20.3$ & $8.5 \pm 1.5$ & $5.8-12.0$ \\
\hline Alcohol intake $(\mathrm{g} / \mathrm{d})$ & $1.7 \pm 3.5$ & $0.0-13.5$ & $4.0 \pm 6.1^{* 1}$ & $0.2-18.5$ \\
\hline \multicolumn{5}{|l|}{ Smoking $(\%)$} \\
\hline Current & 21.6 & - & $11.5^{* 2}$ & - \\
\hline Past & 33.4 & - & 11.5 & - \\
\hline Never & 45.0 & - & 77.0 & - \\
\hline \multicolumn{5}{|l|}{ Dieting (\%) } \\
\hline Yes & 41.2 & - & $15.4^{* 2}$ & - \\
\hline No & 58.8 & - & 84.6 & - \\
\hline \multicolumn{5}{|l|}{ Physical Activity (\%) } \\
\hline Low & 84.3 & - & $61.5^{* 2}$ & - \\
\hline Moderate & 15.7 & - & 38.5 & - \\
\hline Active & 0.0 & - & 0.0 & - \\
\hline
\end{tabular}

${ }^{1}$ Mann Whitney U-test; ${ }^{\text {2 }}$ chi-square test; SD - standard deviation. 
Table 3. Association of Serum Retinol and $\alpha$-Tocopherol with Study Variables

\begin{tabular}{|c|c|c|c|c|}
\hline \multirow{2}{*}{ Variables } & \multicolumn{2}{|c|}{ Retinol } & \multicolumn{2}{|c|}{$\alpha$-Tocopherol } \\
\hline & $\mathbf{r}$ & $\mathbf{p}$ & $\mathbf{r}$ & $\mathbf{p}$ \\
\hline Serum retinol $(\mu \mathrm{mol} / \mathrm{L})$ & - & - & 0.386 & 0.001 \\
\hline Serum $\alpha$-tocopherol $(\mu \mathrm{mol} / \mathrm{L})$ & 0.386 & $0.001^{\mathrm{a}}$ & - & - \\
\hline TChol (mmol/L) & 0.393 & $<0.0001$ & 0.682 & $<0.0001$ \\
\hline $\mathrm{TG}(\mathrm{mmol} / \mathrm{L})$ & 0.274 & 0.016 & 0.426 & $<0.0001$ \\
\hline HDL cholesterol (mmol/L) & 0.110 & 0.430 & 0.485 & $<0.0001$ \\
\hline LDL cholesterol (mmol/L) & 0.320 & 0.019 & 0.520 & $<0.0001$ \\
\hline Age (years) & 0.268 & 0.018 & 0.440 & $<0.0001$ \\
\hline BMI $\left(\mathrm{kg} / \mathrm{m}^{2}\right)$ & 0.099 & 0.401 & 0.274 & 0.019 \\
\hline$\%$ FM (\%) & 0.110 & 0.339 & 0.231 & 0.042 \\
\hline WHR & 0.139 & 0.227 & 0.287 & 0.011 \\
\hline Energy intake (kcal/d) & -0.162 & 0.159 & -0.206 & 0.072 \\
\hline Fat intake $(\mathrm{g} / \mathrm{d})$ & 0.093 & 0.417 & 0.109 & 0.345 \\
\hline Vitamin $A$ intake $(\mu \mathrm{g} / \mathrm{d})$ & 0.017 & 0.881 & 0.015 & 0.891 \\
\hline Vitamin E intake (mg/d) & 0.045 & 0.695 & 0.074 & 0.518 \\
\hline Alcohol intake $(\mathrm{g} / \mathrm{d})$ & -0.125 & 0.284 & -0.198 & 0.088 \\
\hline Smoking (\%) & 0.300 & 0.008 & 0.227 & 0.047 \\
\hline Dieting (\%) & -0.039 & 0.733 & -0.352 & 0.002 \\
\hline Physical activity (\%) & -0.070 & 0.542 & -0.059 & 0.606 \\
\hline
\end{tabular}

Notes: $\mathrm{r}$ - Pearson's correlation coefficient; ${ }^{\mathrm{a}}$ - significant correlations are marked in bold numbers.

predictors of its serum concentration. The strongest positive marker of serum level of $\alpha$-tocopherol was serum total cholesterol concentration TChol. Serum $\alpha$-tocopherol concentration were also positively associated with BMI, but negatively related to past dieting behaviour and total energy intake. Intakes of fat and vitamin E and A, age, serum triglyceride concentration TG, smoking, alcohol consumption and physical activity were unrelated to serum levels of retinol or $\alpha$-tocopherol. The effects of percentage of body fat and waist to hip ratio were examined independently in the full model. Both \%FM and WHR were significantly associated with serum $\alpha$-tocopherol concentration with beta $=0.2621 ; \mathrm{p}=0.020$ and beta $=0.177$; $\mathrm{p}=0.050$, respectively. However, none of these factors changed relation with other variables, nor did their addition improve the model adjusted $R^{2}$.

\section{DISCUSSION}

The present study indicated that several dietary and lifestyle factors as well as serum lipids were predictors of serum retinol or $\alpha$-tocopherol concentrations. As expected, serum retinol concentration was associated with a few predictors which had only little explanatory ability. In contrast, more substantial amounts of the variability in serum $\alpha$-tocopherol concentration could be explained by serum lipids concentrations, dietary and lifestyle factors.

Table 4. Predictors of Serum Retinol and $\alpha$-Tocopherol Concentration in Multivariate Linear Regression Analyses

\begin{tabular}{|c|c|c|c|c|}
\hline \multirow{2}{*}{ Variables } & \multicolumn{2}{|c|}{ Retinol } & \multicolumn{2}{|c|}{$\alpha$-Tocopherol } \\
\hline & Beta-Coefficient & $\mathbf{p}$ & Beta-Coefficient & $\mathbf{p}$ \\
\hline TChol (mmol/L) & 0.311 & $0.019^{a}$ & 0.443 & $<0.0001$ \\
\hline $\mathrm{TG}(\mathrm{mmol} / \mathrm{L})$ & 0.035 & 0.675 & 0.059 & 0.519 \\
\hline Age (years) & 0.176 & 0.212 & 0.097 & 0.349 \\
\hline Energy intake (kcal/d) & -0.258 & 0.042 & -0.265 & 0.038 \\
\hline Fat intake $(\mathrm{g} / \mathrm{d})$ & 0.197 & 0.229 & 0.039 & 0.747 \\
\hline $\operatorname{Vitamin} \mathrm{A}$ intake $(\mu \mathrm{g} / \mathrm{d})$ & 0.040 & 0.727 & - & - \\
\hline Vitamin E intake (mg/d) & - & - & 0.089 & 0.411 \\
\hline Alcohol intake $(\mathrm{g} / \mathrm{d})$ & 0.047 & 0.690 & 0.050 & 0.589 \\
\hline Smoking (\%) & 0.158 & 0.194 & 0.094 & 0.276 \\
\hline Dieting (\%) & 0.017 & 0.898 & -0.287 & 0.005 \\
\hline Physical activity (\%) & 0.067 & 0.581 & -0.100 & 0.274 \\
\hline $\operatorname{BMI}\left(\mathrm{kg} / \mathrm{m}^{2}\right)$ & 0.023 & 0.870 & 0.271 & 0.015 \\
\hline Adjusted $R^{2}$ & \multicolumn{2}{|c|}{0.163} & \multicolumn{2}{|c|}{0.535} \\
\hline
\end{tabular}

${ }^{\mathrm{a}}$ Significant correlations are marked in bold numbers. 
As in other studies we observed a high correlation between serum retinol and $\alpha$-tocopherol levels and serum total cholesterol concentration TChol [15, 17, 40-42]. The correlation with TChol is well known and explained by the fact that $\alpha$-tocopherol circulates in blood as part of a lipoprotein complex [43, 44]. We found an inverse association between energy intake and serum retinol and $\alpha$-tocopherol concentrations. This is in agreement with some previous studies [4547], but others have shown positive or no relation of energy intake to blood $\alpha$-tocopherol or retinol levels [14, 47, 48]. The results of our analysis demonstrated also that in this population, dietary intake of vitamin $\mathrm{A}$ and $\mathrm{E}$ was not predictive of serum retinol or $\alpha$-tocopherol concentrations. These findings are in line with previous reports [14, 17, 47, $49,50]$. No correlation between dietary vitamin A and serum retinol level may be due to the fact that the amount of retinol in the circulating body pool is highly regulated and is essentially homeostatically controlled to body stores [8]. Some studies have also shown that iron deficiency seems to deteriorate vitamin A metabolism leading to reduction of serum retinol [51] and that vitamin A supplementation did not affect serum retinol concentrations [17, 52-54]. Whereas, it was observed that vitamin $\mathrm{E}$ intake was significantly associated with serum concentrations of $\alpha$-tocopherol only when vitamin supplement users were included in the analyses [14, 17, 55-57]. Although, small statistically significant association of dietary $\alpha$-tocopherol with serum $\alpha$-tocopherol among non-supplement users was observed by White et al. [40], but they used database that estimated dietary $\alpha$-tocopherol separately. However, they also indicated that $\alpha$-tocopherol measured by a food frequency questionnaire only explained about $1 \%$ of the (lipid-adjusted) variance of serum $\alpha$-tocopherol levels. Whereas, supplement use explained $45 \%$ of the variance in serum $\alpha$-tocopherol. The lack of associations between vitamin $\mathrm{A}$ and $\mathrm{E}$ intake and serum concentrations of retinol and $\alpha$-tocopherol suggest that these antioxidant biomarkers are influenced more by factors other than their intake [51, 58].

Concentration of serum retinol and $\alpha$-tocopherol varies according to age and some studies reported a positive association between age and their serum concentration [48, 56, 59]. However, in our study age was positively related to serum retinol and $\alpha$-tocopherol concentration in crude analyses, but the effect of age as a predictor of their serum levels disappeared when other variables were controlled. Similarly, Gascon-Vila et al. [47] and Kitamura et al. [41] observed that age was no longer associated with serum $\alpha$-tocopherol after standardization of serum $\alpha$-tocopherol by other factors.

In this study, we did not found an association of smoking and alcohol consumption with serum retinol or $\alpha$-tocopherol concentration. It is similar with results of others, who also observed that low intakes of alcohol have not been related to a decrease of antioxidant vitamins in the human body [14, $45,47,54]$. It is known that alcohol may increase oxidation of $\alpha$-tocopherol and retinol and reduce body stores [12, 54, 60], but the oxidative stress by alcohol depends on the amount and frequency of alcoholic beverage consumed [61, 62]. Alcohol consumption has also been associated with increased serum retinol [14, 59] or $\alpha$-tocopherol [41] concentration. Evidence of a relation between tobacco smoking and $\alpha$-tocopherol and retinol status is controversial. Some studies indicated that smokers had significantly lower serum levels of $\alpha$-tocopherol $[15,30]$ or retinol [15, 42, 63] whereas others reported of no effect of tobacco smoking on their serum concentration $[14,41,63,64,65]$.

As is presented in Table 2 serum retinol and $\alpha$-tocopherol concentrations fall within the upper accepted normal ranges, i.e. $>0.7-2.8 \mu \mathrm{mol} / \mathrm{L}$ for retinol, and $>16.2-46.0 \mu \mathrm{mol} / \mathrm{L}$ for $\alpha$-tocopherol for healthy adults [9, 11, 38, 39]. Compare to results of serum concentrations of retinol and $\alpha$-tocopherol in control healthy, non-smoking, middle-aged female subjects from five European countries (France, Northern Ireland, Republic of Ireland, The Netherlands and Spain) reported by Olmedilla et al. [38] the statistically significantly higher levels of these both vitamins were observed in each female subjects groups studied here (see Table 5 and Fig. 2). Considering the serum $\alpha$-tocopherol/TChol ratio, a more reliable marker for vitamin $\mathrm{E}$ nutritional status $[35,38]$, one can observe the values above the cut-off point of $2.2 \mu \mathrm{mol} / \mathrm{mmol}$ in both groups of females studied here (see Table 2). However, as is seen in Fig. (2) and Table 5, this ratio for normalweight Polish females, i.e. $6.13 \mu \mathrm{mol} / \mathrm{mmol}$, is higher than reported previously [38] for French and Dutch females, i.e. 5.89 and $5.37 \mu \mathrm{mol} / \mathrm{mmol}$, respectively, and in comparison with Lebanese females [66], i.e. $5.10 \mu \mathrm{mol} / \mathrm{mmol}$. However, in female subject studied here the serum $\alpha$-tocopherol/TChol ratio was lower than in case of Irish and Spanish females (7.60 and $6.53 \mu \mathrm{mol} / \mathrm{mmol}$, respectively), and in large, multi race sample of adult females from Indianapolis area (IN, USA) [59], i.e. $7.70 \mu \mathrm{mol} / \mathrm{mmol}$. There was no significance difference between mean serum retinol and $\alpha$-tocopherol concentration among ov/ob and normal weight female participants in the study reported here. Our results are consistent with those previously described in Italy [49], Greece [47], France [35, 45], Spain [35, 67] and in USA adult female populations from urbanized areas $[17,35]$. In contrast to our findings, Viroonudomphol et al. [18], Ohrvall et al. [68] reported lower serum levels of $\alpha$-tocopherol concentration in Thai and Swedish adult women populations. Similarly, Moor de Burgos et al. [19] outlined significantly decreased serum retinol concentration and a higher prevalence of vitamin A deficiency in the ov/ob middle-aged female subjects from Poland during a period of severe nation-wide economical disturbances and social transformations. However, in the study reported here, with developed multiple liner regression model a BMI, WHR as well as \%FM were found to be positive determinants of serum $\alpha$-tocopherol, but not retinol concentrations. This is in agreement with results of Wallstrom et al. [16] who found a significant positive association of serum $\alpha$-tocopherol with general and central obesity, and with findings of Gascon-Vila et al. [47] and Ascherio et al. [14] who reported that BMI is a positive predictor of serum $\alpha$-tocopherol concentrations. However, it should be noted that some studies have shown inversely association between serum $\alpha$-tocopherol concentrations and BMI [18, 40, 59].

It should be pointed out that a major limitation of this study is the relatively small size of the study population as well as restricting participants to adult female subjects only, which limit the generalizability of our conclusions. Furthermore, the serum measures reflect concentrations at a single point in time. Whereas, daily and seasonal variation in blood retinol and $\alpha$-tocopherol concentrations are considerable [15, $35,69]$. In addition, many of the factors (physical activity, smoking, past dieting behaviours) relied on self-report. The 
Table 5. Mean Serum Concentrations of Retinol, $\alpha$-Tocopherol and $\alpha$-Tocopherol/TChol Ratio as Reported in Various Studies on the Representative Sample Populations of Urban, Middle-aged Female Subjects in Five European Countries [38], Lebanon [66], USA [59] and Poland (Present Study)

\begin{tabular}{|c|c|c|c|c|c|c|}
\hline Country & $\begin{array}{c}\text { Number of } \\
\text { Female Subjects }\end{array}$ & $\begin{array}{c}\text { Mean } \\
\text { Age }\end{array}$ & $\begin{array}{c}\text { Retinol } \\
(\mu \mathrm{mol} / \mathrm{L})\end{array}$ & $\begin{array}{c}\alpha \text {-Tocopherol } \\
(\mu \mathrm{mol} / \mathrm{L})\end{array}$ & $\begin{array}{c}\alpha \text {-Tocopherol/TChol } \\
\text { Ratio }(\mu \mathrm{mol} / \mathrm{mmol})\end{array}$ & Ref. \\
\hline France & 37 & 35.9 & 1.87 & 26.50 & 5.89 & {$[38]$} \\
\hline Northern Ireland & 33 & 35.1 & 1.97 & 27.60 & 7.60 & {$[38]$} \\
\hline Ireland & 33 & 31.9 & 1.83 & 26.50 & 7.82 & {$[38]$} \\
\hline The Netherlands & 39 & 33.1 & 2.10 & 25.50 & 5.37 & {$[38]$} \\
\hline Spain & 32 & 36.1 & 1.78 & 28.30 & 6.53 & {$[38]$} \\
\hline Lebanon & 538 & 43.5 & 1.95 & 24.43 & 5.10 & {$[66]$} \\
\hline USA & 631 & 38.2 & 1.82 & 29.34 & 7.70 & [59] \\
\hline Poland - nw group & 26 & 40.0 & 2.33 & 29.90 & 6.13 & This study \\
\hline Poland - ov/ob group & 51 & 46.6 & 2.39 & 33.10 & 6.35 & This study \\
\hline
\end{tabular}

lack of association of intake of vitamin A and E with serum retinol or $\alpha$-tocopherol concentration may be due to the fact that our study were based on nutritional databases that estimated dietary vitamin $\mathrm{A}$ and $\mathrm{E}$ in retinol and $\alpha$-tocopherol equivalents. Another explanation for the absence of a correlation may be the fact that serum retinol concentrations are only responsive to vitamin A intake in individuals with inadequate vitamin A status. The final limitations is that the dietary data were collected only once, whereas seasonal variation of dietary intake of vitamin $A$ and $E$ have been reported $[35,58,67,70,71]$.

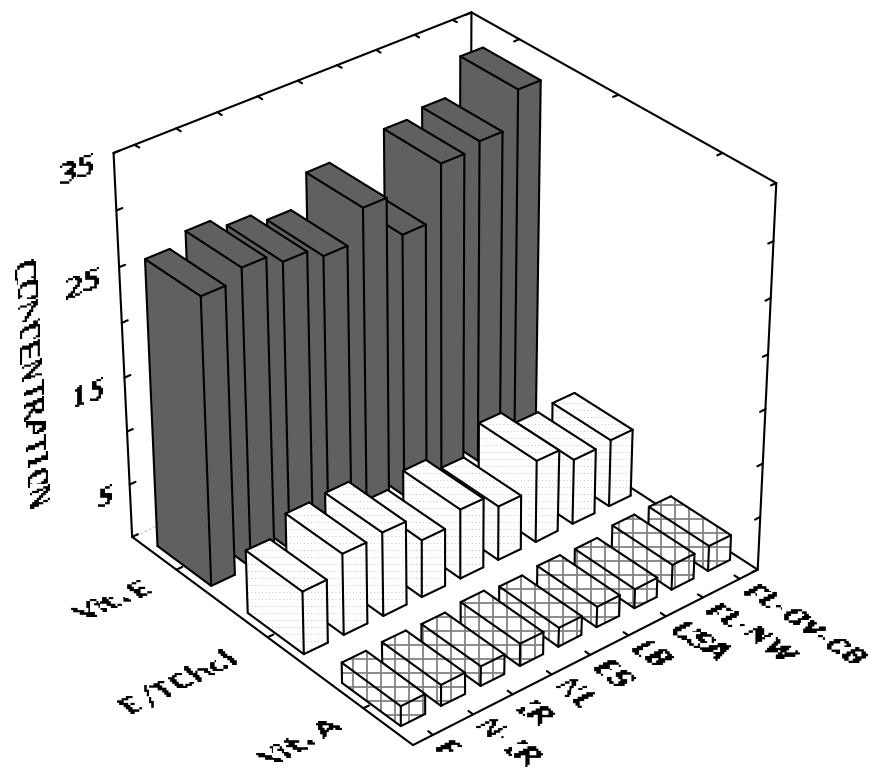

Fig. (2). Comparison of mean serum concentrations of retinol (Vit.A, $\mu \mathrm{mol} / \mathrm{L}$ ), $\alpha$-tocopherol (Vit.E, $\mu \mathrm{mol} / \mathrm{L}$ ) and $\alpha$ tocopherol/TChol ratio (E/TChol, $\mu \mathrm{mol} / \mathrm{mmol}$ ) observed for a sample populations of middle-aged female subjects in five European countries [38], Lebanon [66], USA [59] and Poland (present study). Code: $\mathrm{F}=$ France, N-IR $=$ North Ireland, IR $=$ Ireland, NL = The Netherlands, ES = Spain, $\mathrm{LB}=$ Lebanon, PL-NW = Poland normal weight subjects, Poland-OV/OB = Poland overweight/obese subjects.

\section{CONCLUSION}

The applied here analytical method for determination of serum retinol and $\alpha$-tocopherol consisted of a simple, fast, efficient and reproducible deproteinization procedure and subsequent single run, specific, selective, precise, accurate and robust reversed-phase HPLC method with switched wavelength UV detection throughout the whole range of clinically relevant concentrations of these vitamins. However, the whole-up throughput of this analytical protocol is limited only to the 5 samples per hour and 60 samples in working day which would be confusing for utility and versality in practice of massive clinical assessments and large cohort screening studies on nutrition status.

Considering the female subject our results indicated that the strongest factor affecting retinol and $\alpha$-tocopherol status in this group is serum total cholesterol concentration TChol. It was observed that lifestyle and dietary variables are also relevant determinants of serum concentrations of these vitamins, especially in case of serum $\alpha$-tocopherol level. Considering the costs related to treatment of the patients in the risk groups and logistic difficulties in estimating reliable retinol and $\alpha$-tocopherol status, our results on the multivariate linear regression model may be useful for identifying groups at risk of inadequacy or deficiency. However, as in some previous studies $[15,18,48,50,52,58]$, our findings indicated that dietary intake of vitamin $\mathrm{A}$ and $\mathrm{E}$ are poor predictors for serum retinol and $\alpha$-tocopherol concentrations. The main finding of our study is that obesity in apparently healthy adult female subjects is not associated with decreased serum retinol and $\alpha$-tocopherol levels. The suggested association of abdominal obesity with increasing risk for cardiovascular disease may be result of other factors rather than the effect of depletion serum $\alpha$-tocopherol concentration. So our study did not support the hypothesis that the inverse association between serum $\alpha$-tocopherol concentration and abdominal adiposity may partly explain why this adiposity is a risk factor for coronary heart disease $[68,72]$.

\section{ACKNOWLEDGEMENT}

This work was supported by internal grant CM-UMKBW-68-06.
ABBREVIATIONS
$\mathrm{BMI}=$ Body mass index
$\% \mathrm{FM}=$ Percentage of body fat
$\mathrm{HDL}=$ High density lipoproteins 


LDL $=$ Low density lipoproteins
LOD $=$ Limit of detection
LOQ $=$ Limit of quantitation
nw $=$ Normal weight subjects
ov/ob $=$ Overweight/obese subjects
RBP4 $=$ Retinol binding protein 4
SOD1 $=$ Superoxide dismutase 1
SOD2 $=$ Superoxide dismutase 2
TChol $=$ Serum total cholesterol concentration
TG $=$ Serum total triglicerides concentration
WHR $=$ Waist to hip ratio

\section{REFERENCES}

[1] Rock, C.L.; Jacob, R.A.; Bowen, P.E. J. Am. Diet. Assoc., 1996, 96, 693.

[2] Salonen, J.T.; Nyssonen, K.; Tuomainen, T.; Maenpaa, P.H.; Korpela, H.; Kaplan, G.A.; Lynch, J.; Helmrich, S.P.; Salonen, R. $B M J, 1995,311,1124$.

[3] Hercberg, S.; Galan, P.; Preziosi, P.; Bertrais, S.; Mennen, L.; Malvy, D.; Roussel, A.M.; Favier, A.; Briancon, S. Arch. Intern. Med., 2004, 164, 2335.

[4] Hodis, H.N.; Mack, W.J.; LaBree, L.; Cashin-Hemphill, L.; Sevanian, A.; Johnson, R.; Azen, S.P. JAMA, 1995, 273,1849.

[5] Schuster, G.U.; Kenyon, N.J.; Stephensen, C.B. J. Immunol., 2008, $180,1834$.

[6] Valtuena, S.; Pellegrini, N.; Franzini, L.; Bianchi, M.A.; Ardigo, D.; Del Rio, D.; Piatti, P.; Scazzina, F.; Zavaroni, I.; Brighenti, F. Am. J. Clin. Nutr., 2008, 87, 1290.

[7] Fang, Y.Z.; Yang, S.; Wu, G. Nutrition, 2002, 18, 872.

[8] Olson, J.A. Biochemistry of vitamin A and carotenoids. In: Vitamin A Deficiency: Health, Survival, and Vision; Sommer A., West K. P., Eds.; Oxford University Press, New York, 1996, pp. 221.

[9] Human Vitamin and Mineral Requirements. Report of a joint FAO/WHO expert consultation - Bangkok, Thailand. Food and Agriculture Organization of the United Nations. World Health Organization. Food and Nutrition Divison, Rome, 2001, pp. 7, 87, 121.

[10] Packer, L. Am. J. Clin. Nutr., 1991, 53,1050S.

[11] Foksinski, M.; Gackowski, D.; Rozalski, R.; Siomek, A.; Guz, J.; Szpila, A.; Dziamian, T.; Olinski, R. Eur. J. Nutr., 2007, 46, 174.

[12] Drevon, C.A. Free Radic. Res. Commun., 1991, 14, 229.

[13] Blomhoff, R. Physiol. Rev., 1991, 71, 951.

[14] Ascherio, A.; Stampfer, M.J.; Colditz, G.A.; Rimm, E.B.; Litin, L.; Willett, W.C. J. Nutr., 1992, 122,1792.

[15] Faure, H.; Preziosi, P.; Roussel, A.M.; Bertrais, S.; Galan, P.; Hercberg, S.; Favier, A. Eur. J. Clin. Nutr., 2006, 60, 706.

[16] Wallstrom, P.; Wirfalt, E.; Lahmann, P.H.; Gullberg, B.; Janzon, L.; Berglund, G. Am. J. Clin. Nutr., 2001, 73, 777.

[17] Hebert, J.R.; Hurley, T.G.; Hsieh, J.; Rogers, E.; Stoddard, A.M.; Sorensen, G.; Nicolosi, R.J. Am. J. Epidemiol., 1994, 140, 132.

[18] Viroonudomphol, D.; Pongaew, P.; Tungtrongchitr, R.; Changbumrung, S.; Tungtrongchitr, A.; Phonrat, B.; Vudhivai, N.; Schelp, F.P. Asia Pac. J. Clin. Nutr., 2003, 12, 73.

[19] Moor de Burgos, A.; Wartanowicz, M.; Ziemlanski, S. Eur. J. Clin. Nutr., 1992, 46, 803.

[20] Cercato, C.; Mancini, M.C.; Arguello, A.M.C.; Passos, V.Q.; Villares, S.M.F.; Halpern, A. Rev. Hosp. Clin. Fac. Med. Sao. Paulo, 2004, 59, 113.

[21] Bajzova, M.; Kovacikova, M.; Vikova, M.; Klimcakova, E.; Polak, J.; Kovacova, Z.; Viguerie, N.; Vedral, T.; Mikulasek, L.; Sramkova, P.; Srp, A.; Hejnova, J.; Langin, D.; Stich V. Physiol. Res., 2007, in print

[22] Jaworowska, A.; Bazylak, G. Adv. Med.Sci., 2007, 52, 240.

[23] Buszewski, B.; Krupczynska, K.; Bazylak, G. Comb. Chem. High Throughput Screen., 2004, 7, 383.

[24] Luchsinger, J.A.; Noble, J.M.; Scarmeas, N. Curr. Neurol. Neurosci. Rep., 2007, 7, 366.
[25] Charzewska, J.; Rogalska-Niedzwiedz, H.; Chojnowska, Z.; Chabrom, E.; Wojtasik, A. Instruction for 24-hour recall method. IZZ Press, Warsaw, 1997 [in Polish].

[26] Szponar, L.; Wolicka, K.; Rychlik, E. Atlas of photographs of food products and dishes. IZZ Press, Warsaw, 2000 [in Polish].

[27] Kunachowicz, H.; Nadolna, I.; Przygoda, B.; Iwanow, K. Tables of nutritious value of food products. IZZ Press, Warsaw, 1998 [in Polish].

[28] Durnin, J.V.; Womersley, J. Br. J. Nutr., 1974, 32, 77.

[29] Friedewald, W.T.; Levy, R.I.; Fredrickson, D.S. Clin. Chem., 1972, $18,499$.

[30] Liu, D.; Desiderio, D.M. J. Chromatogr., 1987, 422, 61.

[31] Milne, D.B.; Botnen, J. Clin. Chem., 1986, 32, 874.

[32] Nirungsan, K.; Thongnopnua, P. Biomed. Chromatogr. 2006, 20, 774.

[33] Olmedilla-Alonso, B.; Granado-Lorencio, F.; Blanco-Navarro, I. Clin. Biochem., 2005, 38, 444.

[34] Granado-Lorencio, F.; Olmedilla-Alonso, B.; Herrero-Barbudo, C.; Blanco-Navarro, I.; Blazquez-Garcia, S.; Perez-Sacristan, B. Clin. Biochem., 2006, 39, 180.

[35] Olmedilla, B.; Granado, F.; Gil-Martinez, E.; Blanco, I.; RojasHidalgo, E. Clin. Chem., 1997, 43, 1066.

[36] ICH Harmonised Tripartite Guideline. Validation of Analytical Procedures: Text and Methodology Q2(R1). European Medicines Agency-EMEA, November 2005. http://www.emea.eu.int (accessed February 10, 2007).

[37] Poole, C.F.; Kiridena, W.; DeKay, C.; Koziol, W.W.; Rosencrans, R.D. J. Chromatogr. A, 2006, 1115, 133.

[38] Olmedilla, B.; Granado, F.; Southon, S,.; Wright, A.J.A.; Blanco, I.; Gil-Martinez, E.; van der Berg, H.; Corridan, B.; Roussel, A.M.; Chopra, M.; Thurnham, D.I. Brit. J. Nutr., 2001, 85, 227.

[39] Biesalski, H.K.; Schrezenmeir, J.; Weber, P.; Weiss H.E. VitaminePhysiologie, Pathophysiologie, Therapie. Georg Thieme Verlag, Stuttgart-New York, 1997.

[40] White, E.; Kristal, A.R.; Shikany, J.M.; Wilson, A.C.; Chen, C.; Mares-Perlman, J.A.; Masaki, K.H.; Caan, B.J. Ann. Epidemiol., 2001, 11, 136.

[41] Kitamura, Y.; Tanaka, K.; Kiyohara, C.; Hirohata, T.; Tomita, Y.; Ishibashi, M.; Kido, K. Int. J. Epidemiol., 1997, 26, 307.

[42] Vogel, S.; Contois, J.H.; Tucker, K.L.; Wilson, P.W.; Schaefer, E.J.; Lammi-Keefe, C.J. Am. J. Clin. Nutr., 1997, 66, 950.

[43] Perugini, C.; Bagnati, M.; Cau, C.; Bordone, R.; Zoppis, E.; Paffoni, P.; Re, R.; Albano, E.; Bellomo, G. Pharmacol. Res., 2000, 41, 55.

[44] Behrens, W.A.; Thompson, J.N.; Madere, R. Am. J. Clin. Nutr., 1982, 35, 691 .

[45] Galan, P.; Viteri, F.E.; Bertrais, S.; Czernichow, S.; Faure, H.; Arnaud, J.; Ruffieux, D.; Chenal, S.; Arnault, N.; Favier, A.; Roussel, A.M.; Hercberg, S. Eur. J. Clin. Nutr., 2005, 59, 1181.

[46] Neuhouser, M.L.; Rock, C.L.; Eldridge, A.L.; Kristal, A.R.; Patterson, R.E.; Cooper, D.A.; Neumark-Sztainer, D.; Cheskin, L.J.; Thornquist, M.D. J. Nutr., 2001, 131, 2184.

[47] Gascon-Vila, P.; Garcia-Closa, R.; Serra-Majem, L.; Pastor, M.C.; Ribas, L.; Ramon, J.M.; Mariné-Font, A.; Salleras, L. Eur. J. Clin. Nutr., 1997, 51, 723.

[48] Papas, A.; Stacewicz-Sapuntzakis, M.; Lagiou, P.; Bamia, C.; Chloptsios, Y.; Trichopoulou, A. Brit. J. Nutr., 2003, 89, 83.

[49] Palli, D.; Decarli, A.; Russo, A.; Cipriani, F.; Giascosa, A.; Amadori, D.; Salkeld, R.; Salvini, S.; Buiatti, E. Eur. J. Nutr., 1999, 38, 90.

[50] Jarvinen, R.; Knekt, P.; Seppanen, R.; Heinonen, M.; Aaran, R.K. Eur. J. Clin. Nutr., 1993, 47, 31.

[51] Oliveira, J.M.; Michelazzo, F.B.; Stefanello, J.; Rondo, P.H. Nutr. Rev., 2008, 66, 141.

[52] Johnson, E.J.; Krall, E.A.; Dawson-Hughes, B.; Dallal, G.E.; Russell, R.M. J. Am. Coll. Nutr., 1992, 11, 682.

[53] Willett, W.C.; Stampfer, M.J.; Underwood, B.A.; Taylor, J.; Hennekens, C.H. Am. J. Clin. Nutr., 1983, 38, 559.

[54] Gueguen, S.; Pirollet, P.; Leroy, P.; Guilland, J.C.; Arnaud, J.; Paille, F.; Siest, G.; Visvikis, S.; Hercberg, S.; Herbeth, B. J. Am. Coll. Nutr., 2003, 22, 303.

[55] Jacques, P.F.; Sulsky, S.I.; Sadowski, J.A.; Phillips, J.C.C.; Rush, D.; Willett, W.C. Am. J. Clin. Nutr., 1993, 57, 182.

[56] Sinha, R.; Patterson, B.H.; Mangels, A.R.; Levander, O.A.; Gibson, T.; Taylor, P.R.; Block, G. Cancer Epidemiol. Biomarkers Prev., 1993, 2, 473 . 
[57] El-Sohemy, A.; Baylin, A.; Ascherio, A.; Kabagambe, E.; Spiegelman, D.; Campos, H. Am. J. Clin. Nutr., 2001, 74, 356.

[58] Pachocka, L.M.; Bulhak-Jachymczyk, B.; Klosiewicz-Latoszek, L.; Stolarska, I.; Grzybek, A.; Targosz, U. Ann. Acad. Med. Stetin., 2005, 51 (Suppl. 1), 119.

[59] Rock, C.L.; Thornquist, M.D.; Kristal, A.R.; Patterson, R.E.; Cooper, D.A.; Neuhouser, M.L.; Neumark-Sztainer, D.; Cheskin, L.J. J. Nutr., 1999, 129, 855.

[60] Leo, M.A.; Lieber, C.S. Am. J. Clin. Nutr., 1999, 69, 1071.

[61] van der Gaag, M.S.; van den Berg, R.; van den Berg, H.; Schaafsma, G.; Hendriks, H.F. Eur. J. Clin. Nutr., 2000, 54, 586.

[62] Lecomte, E.; Herberth, B.; Pirrollet, P.; Chancerelle, Y.; Aruand, J.; Musse, N.; Paille, F.; Siest, G.; Artur, Y. Am. J. Clin. Nutr., 1994, 60, 255

[63] Nierenberg, D.W.; Stukel, T.A.; Baron, J.A.; Dain, B.J.; Greenberg, E.R. Am. J. Epidemiol., 1989, 130, 511.

[64] Bolton-Smith, C.; Casey, C.E.; Gey, K.F.; Smith, W.C.; TunstallPedoe, H. Br. J. Nutr., 1991, 65, 337.
[65] Ross, M.A.; Crosley, L.K.; Brown, K.M.; Duthie, S.J.; Collins, A.C.; Arthur, J.R.; Duthie, G.G. Eur. J. Clin. Nutr., 1995, 49, 861.

[66] Obeid, O.A.; Al-Ghali, R.M.; Khogali, M.; Hwalla, N. Int. J. Vitamin. Nutr. Res., 2006, 76, 3.

[67] Serra-Majem, L.; Pastor-Ferrer, M.C.; Castell, C.; Ribas-Barba, L Roman-Vinas, B.; Ribera, L.F.; Plasencia, A.; Salleras, L. Public Health Nutr., 2007, 10, 1379.

[68] Ohrvall, M.; Tengblad, S.; Vessby, B. J. Int. Med., 1993, 234, 53.

[69] Tangney, C.C.; Shekelle, R.B.; Raynor, W.; Gale, M.; Betz, E.P. Am. J. Clin. Nutr., 1987, 45, 764.

[70] Zou, X.N.; Taylor, P.R.; Mark, S.D.; Chao, A.; Wang, W.; Dawszy, S.M.; Wu, Y.P.; Qiao, Y.L.; Zheng, S.F. Int. J. Vitam. Nutr. Res., 2002, 72,375 .

[71] Sahar, D.R.; Froom, P.; Harare, G.; Yerushalmi, N.; Lubin, F.; Kristal-Boneh, E. Eur. J. Clin. Nutr., 1999, 53, 395

[72] Palmieri, V.O.; Grattagliano, I.; Portincasa, P.; Palasciano, G. $J$ Nutr., 2006, 136, 3022.

(C) Jaworowska and Bazylak; Licensee Bentham Open.

This is an open access article distributed under the terms of the Creative Commons Attribution License (http://creativecommons.org/licenses/by/2.5/), which permits unrestrictive use, distribution, and reproduction in any medium, provided the original work is properly cited. 